\title{
Protein restriction in chronic renal failure
}

J E Kist-van Holthe tot Echten, J Nauta, W C J Hop, M C J W de Jong, W C C Reitsma-Bierens, S L B Ploos van Amstel, K J van Acker, C M Noordzij, E D Wolff

\begin{abstract}
The aim of the study was to investigate the effect of a protein restricted diet on renal function and growth of children with chronic renal failure. In a multicentre prospective study 56 children (aged 2-18 years) with chronic renal failure were randomly assigned to the protein restricted $(0.8-1 \cdot 1 \mathrm{~g} / \mathrm{kg} /$ day $)$ or the control group. All children were followed up by the same paediatrician and dietitian. After a follow up period of three years there was no significant difference in glomerular filtration rate between children on a protein restricted diet and children of the control group. There was no significant difference in weight with respect to height and height SD score between the protein restricted and the control group. Compliance with the protein restricted diet, as indicated by the prospective diet diaries and the serum urea:creatinine ratio, was good. This study shows that children with chronic renal failure do not benefit from a protein restricted diet.

(Arch Dis Child 1993; 68: 371-375)
\end{abstract}

Department of

Paediatrics, Subdivision

Nephrology, Sophia

Children's Hospital

University Hospital

Rotterdam, Gordelweg

160, 3038 GE Rotterdam,

The Netherlands

J E Kist-van Holthe tot

Echten

J Nauta

C M Noordzi

E D Wolff

Department of

Epidemiology and

Biostatistics, University

Hospital, Rotterdam

W C J Hop

Department of

Paediatrics, Subdivision

Nephrology, University

Hospital, Nijmegen

M C J W de Jong

Department of

Paediatrics, Subdivision

Nephrology, University

Hospital, Groningen

W C C Reitsma-Bierens

Department of

Paediatrics, Subdivision

Nephrology, Academic

Medical Centre,

Amsterdam

S L B Ploos van Amstel

Department of Paediatrics, Subdivision Nephrology, University

Hospital, Antwerp

K J van Acker

Correspondence to:

Dr Kist-van Holthe.

Accepted 29 September 1992
Hyperfiltration, the adaptive response to the loss of functioning kidney mass, is thought to be detrimental to long term kidney function because of the development of glomerulosclerosis. ${ }^{1}$ It is postulated that protein restriction can decrease hyperfiltration and slow down progression of chronic renal failure. ${ }^{2}$ Studies have shown a beneficial effect of a protein restricted diet on renal function in laboratory rats with chronic renal failure. ${ }^{3-5}$ However the growth of some rats on a very low protein diet was impaired.

It is still unknown whether protein restriction can slow down progression of chronic renal failure in man. For children with chronic renal failure one prospective, but not controlled, study has demonstrated a favourable effect of a protein restricted diet on renal function.' A prospective randomised European multicentre study in children is now in progress. ${ }^{8}$ In addition, the potential benefit of protein restriction for children has to be balanced against the risk of retarded growth. We present the results of a three year follow up of a prospective randomised study of the effect of a protein restricted diet on renal function and growth in children with chronic renal failure.

\section{Patients and methods}

GENERAL OUTLINE

In order to minimise interobserver variations one single paediatrician and one dietitian visited the patients in the different centres throughout the course of the study. We regard this as an essential aspect of the study.
PATIENTS

To be eligible for the study the children (age 2-18 years) had to be under treatment for chronic renal failure (glomerular filtration rate (GFR) $15-60 \mathrm{ml} / \mathrm{min} / 1 \cdot 73 \mathrm{~m}^{2}$ ) for at least six months. Excluded from the study were children with cystinosis, oxalosis, lupus erythematosus, severe hypertension (blood pressure exceeding $110 \%$ of the 97 th centile according to Andre and Deschamps ${ }^{9}$ ), and other severe diseases and children on corticosteroid, growth hormone, or erythropoietin treatment. Altogether 56 children were studied. Progressive renal failure was defined as a significant decrease in GFR with respect to the last six to 12 months before the study.

\section{RANDOMISATION}

After an observation period of three months the children were randomly assigned to a protein restricted group $(n=27)$ or a control group $(n=29)$ after stratification for treatment centre. Both groups were well balanced with respect to various baseline characteristics (see the table).

DIET

The children in the protein restricted group were advised to reduce their protein intake to the safe levels of the World Health Organisation (WHO), which vary according to age and gender between 0.8 and $1.1 \mathrm{~g} / \mathrm{kg} /$ day. ${ }^{10}$ The children in the control group were advised to eat at least 1.5 to 2.0 times the safe levels of protein intake, according to age, which equals the normal protein intake for healthy Dutch children. " For all children the target energy intake was at least $100 \%$ of the energy requirement advised by the WHO ${ }^{10} \mathrm{~A}$ paediatrician and dietitian assigned to the study visited the children at the different outpatient clinics every three months.

DIETARY ASSESSMENT

The children and their parents were asked to provide a prospective dietary diary once every

Patient characteristics. Data given are numbers of patients or means $(S D)$

\begin{tabular}{llc}
\hline & $\begin{array}{c}\text { Protein restricted group } \\
(n=27)\end{array}$ & $\begin{array}{l}\text { Control group } \\
(n=29)\end{array}$ \\
\hline Age (years) & $10 \cdot 2(4 \cdot 7)$ & $9 \cdot 3(4 \cdot 5)$ \\
Sex $(M / F)$ & $18 / 9$ & $23 / 6$ \\
GFR $\left(\mathrm{ml} / \mathrm{min} / 1 \cdot 73 \mathrm{~m}^{2}\right)$ & $42(14)$ & $38(14)$ \\
Diagnosis: & 5 & 5 \\
$\quad$ Glomerulopathy & 17 & 18 \\
$\quad$ Uropathy & 5 & 6 \\
$\quad$ Miscellaneous & 11 & 10 \\
Progressive renal failure & $100(17)$ & $97(11)$ \\
Weight for length (\%) & $-1 \cdot 16(1 \cdot 70)$ & $-1 \cdot 57(1 \cdot 17)$ \\
Height SD score & & \\
\hline
\end{tabular}




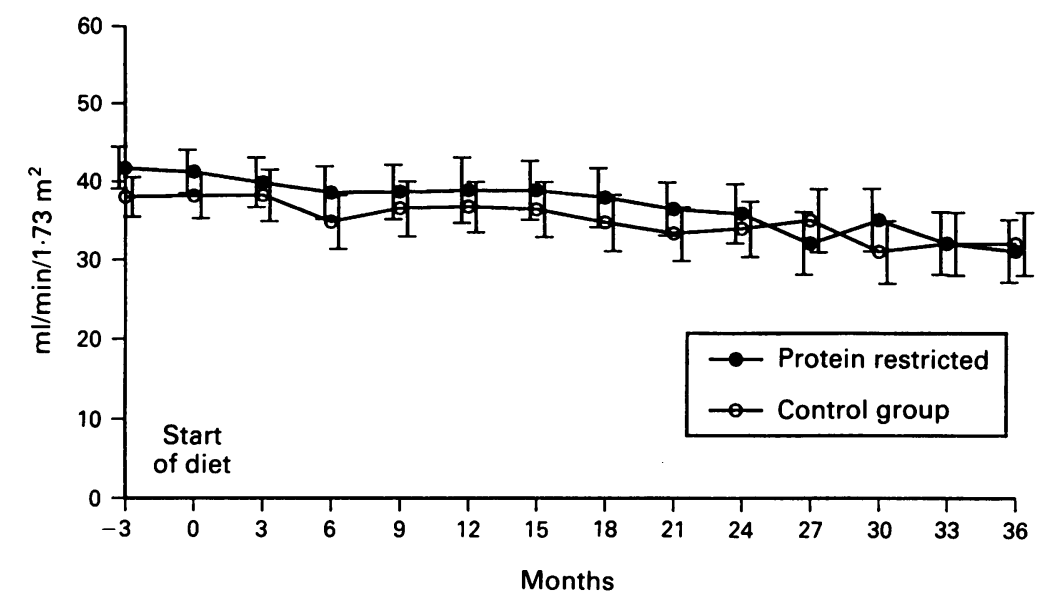

Figure 1 Calculated creatinine clearance: $40 \times$ length $(\mathrm{cm}) /$ creatinine $(\mu \mathrm{mol} / \mathrm{l})$. Bars show SEM.

three months that covered two days during the week and one day in the weekend. The dietitian then discussed the dietary diary with parents and children to be sure that nothing was omitted. Protein and energy intakes were calculated using the Dutch Nutrition Index ${ }^{12}$ and were adjusted if they did not correspond to the prescribed amount.

The serum urea:creatinine ratio was measured every three months. Twenty four hour urinary urea excretion is not a reliable method for assessment of nitrogen intake and was therefore not used to assess dietary compliance. ${ }^{13}$

\section{RENAL FUNCTION}

Once every three months renal function was assessed by means of the endogenous creatinine clearance and the calculated creatinine clearance $(40 \times$ length in $\mathrm{cm} /$ plasma creatinine in $\mu \mathrm{mol} / \mathrm{l}) .{ }^{1+}$ Endogenous creatinine clearance was computed from 24 hour urine collections and plasma creatinine. For the children who were put on renal replacement treatment or died during the study, creatinine clearance and the calculated creatinine clearance were counted as $0 \mathrm{ml} / \mathrm{min} / 1.73 \mathrm{~m}^{2}$ for the remainder of the study. Endogenous creatinine clearance and calculated creatinine clearance are relatively easy noninvasive procedures for assessment of renal

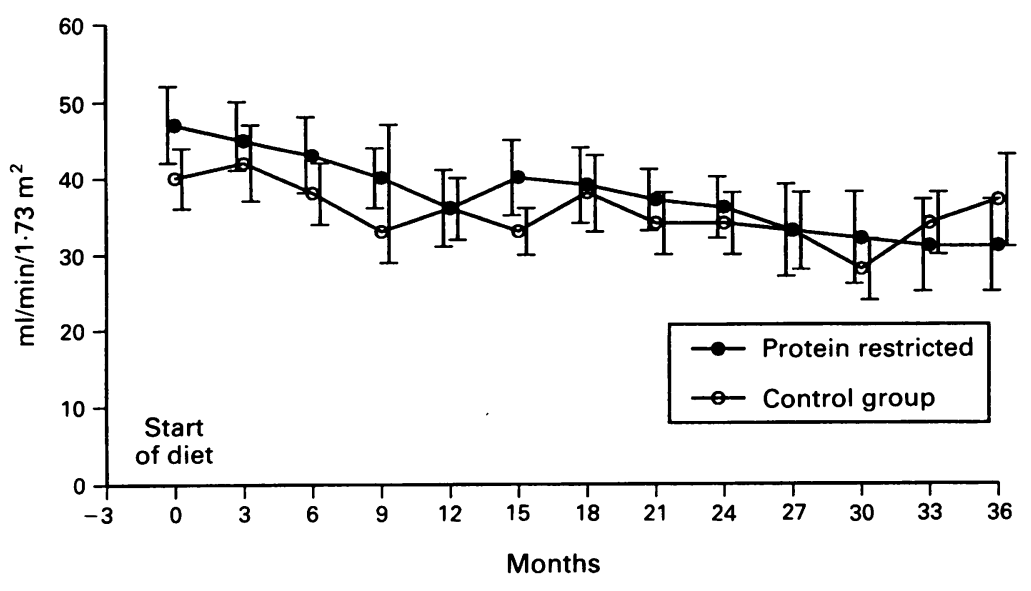

Figure 2 Endogenous creatinine clearance. Bars show SEM. function in children and could therefore be determined at regular three month intervals. Because it is a more invasive procedure, determination of the inulin clearance was only performed after two and three years. This provided validation of the endogenous creatinine clearance and calculated creatinine clearance. Inulin clearance was measured by administration of a continuous inulin infusion and timed collection of urine and plasma samples during a standardised period of the day.

\section{GROWTH AND NUTRITIONAL ASSESSMENT}

Every three months weight, height, upper arm circumference, and triceps skinfold thickness were measured by the same observer. Weight is expressed as weight for height percentage and height as height SD score for healthy Dutch children. ${ }^{\text {is }}$ Delta height SD score was computed as height SD score-height SD score at the time of randomisation. For the children who were put on renal replacement treatment or died during the study, the last weight, height, upper arm circumference, and triceps skinfold thickness were carried forward. Serum albumin and transferrin concentrations were measured every three months as parameters of protein malnutrition. ${ }^{16}$

\section{MISCELLANEOUS PARAMETERS}

Systolic and diastolic blood pressure and haemoglobin, serum uric acid, and bicarbonate concentrations were measured every three months.

\section{STATISTICS}

Data given are mean (SEM). Mean (SD) is given in case it was felt necessary to show the distribution of outcomes. Differences in the means of various parameters between the two groups were assessed for statistical significance using the Mann-Whitney test. In addition, for repeated measurements analysis of variance (BMDP, module $5 \mathrm{~V}$ ) was used to compare changes in the course of time in endogenous creatinine clearance, calculated creatinine clearance, weight with respect to height, height SD score, upper arm circumference, and triceps skinfold thickness. The $p$ values given are two sided; $5 \%$ was considered the limit of significance.

\section{Results}

One child from the control group with mesangiocapillary glomerulonephritis received a course of high dose corticosteroids because of a rapidly progressive phase of his disease three months after randomisation. This child was considered non-evaluable and was excluded from further analysis. None of the other 55 children dropped out of the study during the first two years. In the last year of the study one child from the control group and seven children from the protein restricted group dropped out of the study. Four of these children received growth hormone treatment; this was an exclusion criterion and four children could not comply with the protein restricted diet any longer. 


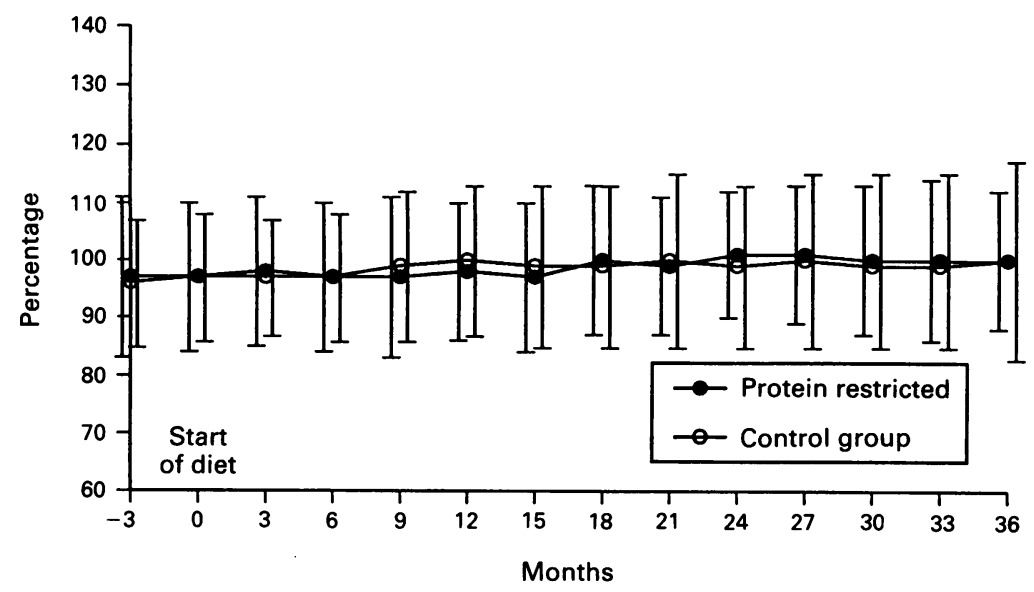

Figure 3 Weight with respect to height. Bars show SD.

RENAL FUNCTION

In the protein restricted group as well as in the control group four children reached end stage renal disease during the course of the study. Creatinine clearances could be calculated for 42 $(75 \%)$ of the 55 patients; for the remaining children urine could not be collected because of incontinence. There was no significant difference between the experimental and the control group in either calculated creatinine clearance or endogenous creatinine clearance during the three year follow up period (figs 1 and 2). In both groups the mean glomerular filtration rate slowly declined: $-2.9(1.0) \mathrm{ml} / \mathrm{min} / 1.73 \mathrm{~m}^{2} /$ year for the protein restricted group and $-2 \cdot 1(0 \cdot 8) \mathrm{ml} / \mathrm{min} /$ $1.73 \mathrm{~m}^{2} /$ year for the control group.

Inulin clearance was measured after two years in 45 patients (six refused, four had reached end stage renal disease) and after three years in 33 patients. The mean inulin clearances after two and three years were $38(16)$ and $36(15) \mathrm{ml} / \mathrm{min} /$ $1.73 \mathrm{~m}^{2}$ respectively for the protein restricted group, which did not significantly differ from 36 (15) and 32 (14) $\mathrm{ml} / \mathrm{min} / 1.73 \mathrm{~m}^{2}$ for the control group. Calculated creatinine clearance and endogenous creatinine clearance correlated significantly with inulin clearance: $r=0.85$ and $r=0.78$, respectively.

GROWTH AND NUTRITIONAL ASSESSMENT

There was no significant difference between the control group and the protein restricted group in

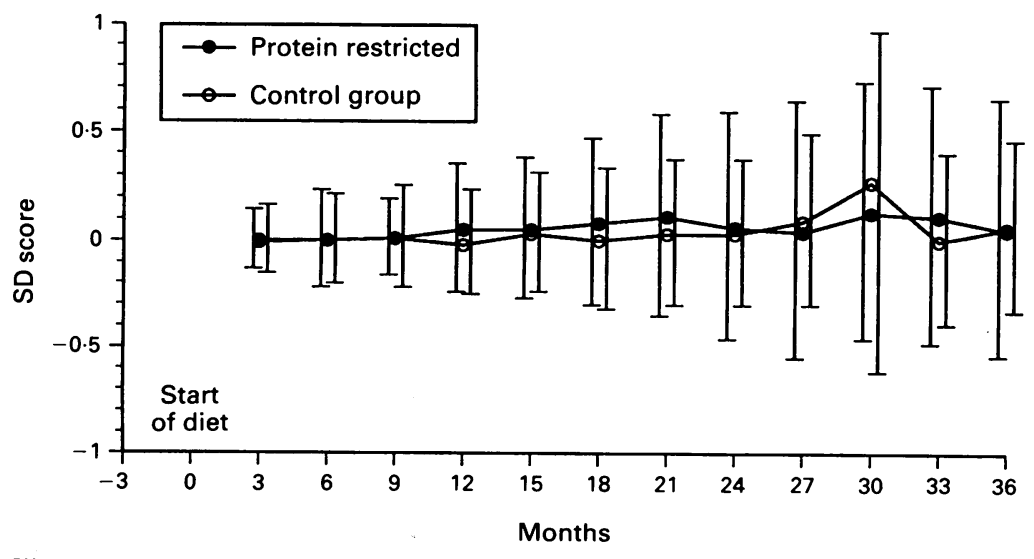

Figure 4 Delta height SD score. Bars show SD. weight with respect to height (fig 3), delta height SD score (fig 4), upper arm circumference, triceps skinfold thickness, and serum albumin and transferrin concentrations during the course of the study.

\section{DIETARY ASSESSMENT}

During the three year follow up period, the mean protein intake of the children in the protein restricted group, calculated from the prospective diet diaries and expressed as a percentage of the prescribed diet, was approximately $100 \%$ (fig 5 ). The mean protein intake of the children in the control group always exceeded $100 \%$ of the prescribed $1 \cdot 5-2 \cdot 0$ times the safe levels for protein intake that approximates the normal protein intake of Dutch children." Energy intake of all children, except one in the control group, was adequate $(>80 \%$ of the advised amount) and there was no significant difference between the children in the protein restricted group and those of the control group. The serum urea:creatine ratio was significantly lower during the entire study period for the protein restricted group with respect to the control group (fig 6).

\section{MISCELLANEOUS PARAMETERS}

There was no significant difference between the protein restricted and the control group in systolic or diastolic blood pressure or in the haemoglobin and bicarbonate concentrations. Uric acid before randomisation was significantly higher in the protein restricted group: 0.41 $(0 \cdot 10) \mathrm{mmol} / \mathrm{l}$ compared with $0.37(0.07) \mathrm{mmol} / \mathrm{l}$ for the control group. This difference did not change during the three year follow up period.

\section{Discussion}

Although it is common practice to advise a protein restricted diet for children with chronic renal failure, this study cannot support the hypothesis that protein restriction can preserve renal function at least during an observation period of three years. Although eight children had to stop the study during the third year, the results in the last year of the study resemble those found in the preceding two years. The results of our study are in accordance with those reported by Rosman $e t a l^{17}$ and Locatelli et $a l,{ }^{18}$ who found no beneficial effect of a protein restricted diet in larger randomised studies of adults (248 patients $^{15}$ and 456 patients $^{16}$ with a degree of chronic renal failure similar to that in our study. Only Ihle et al found a favourable effect of a protein restricted diet $(0.4 \mathrm{~g} / \mathrm{kg} / \mathrm{day})$ in a randomised study of 65 adult patients with severe progressive chronic renal failure (serum creatinine $350-1000 \mu \mathrm{mol} / \mathrm{l}) .{ }^{19}$ But in his study the patients with a protein restricted diet lost significantly more weight and had significantly lower concentrations of serum transferrin and a significantly lower total lymphocyte count, each parameter indicating malnutrition, compared with the control group. Possibly the protein restriction prescribed in our study was not severe enough to protect against haemodynamically mediated glomerular injury when there is a 


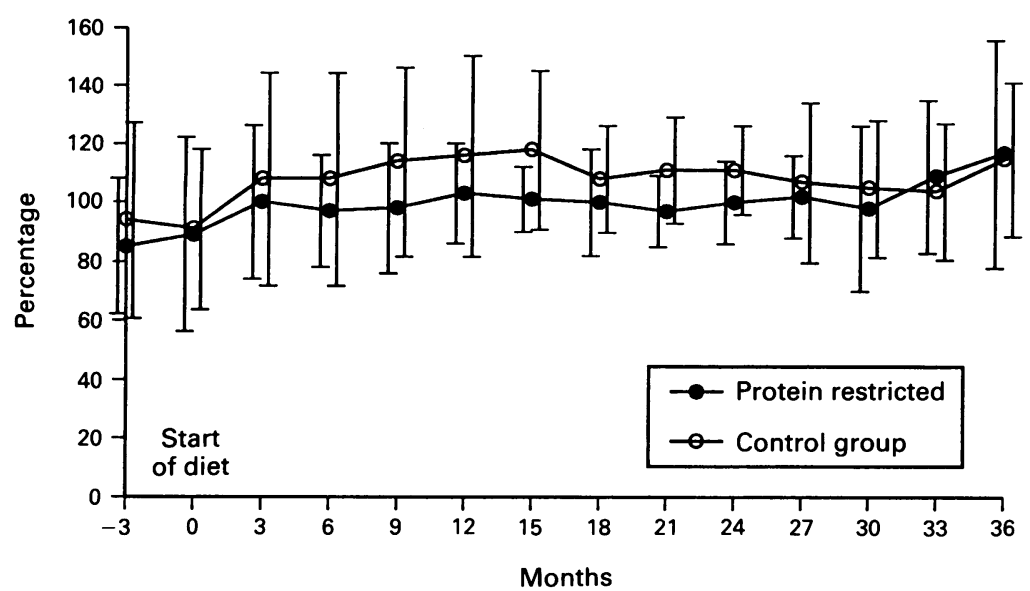

Figure 5 Protein intake. Bars show SD.

significant reduction in functioning nephrons. As children with chronic renal failure are already at risk for growth retardation, however, ${ }^{20-22}$ caution is essential when a protein restricted diet is recommended. The protein restriction followed in our study was combined with an adequate caloric intake and did not cause growth impairment. It does not appear advisable to reduce protein intake below the sale levels recommended by the WHO for protein intake for children in the process of growth, but prospective controlled studies are not available. ${ }^{23}{ }^{24}$ Although the children and their parents were extensively coached and supported during the entire study, diet compliance may not always have been optimal but was in our opinion the best to be achieved. The protein restricted group as a whole had significantly lower serum urea:creatinine ratios compared with the control group.

Those who advocate a low protein diet for the management of patients with renal failure argue that there is an improvement in the patient's wellbeing after a reduction in blood urea concentration. Although this was not extensively studied, our impression was that a few patients in our study did feel better after reducing their protein intake, but in most children this could not be found.

We conclude that the protein restricted diet used in this study has no obvious effect on renal

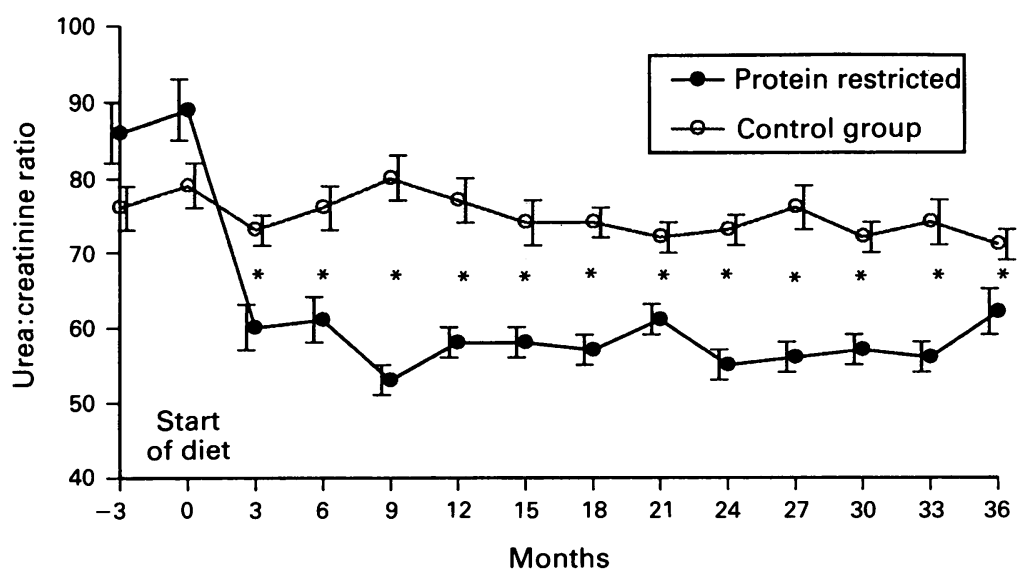

Figure 6 Serum urea:creatinine ratio assessed three months before to 36 months after randomisation. ${ }^{\star} p<0.05=$ statistical difference between the protein restricted group and control group. function in children with chronic renal failure. But it would be too early to state that there is no effect after a more extended observation period. It would also be of interest to analyse the effect of a low protein diet after stratification for underlying primary renal diseases. The relatively small number of our patients did not allow to do this but the analysis of the 200 patients of the European multicentre study did not show such difference, at least for the first study year. ${ }^{8}$ One further important conclusion can be drawn from the study. Long term protein restriction according to the safe levels of the WHO does not negatively influence body growth of these children if adequate amounts of energy are supplied.

When the GFR has fallen below $60 \mathrm{ml} / \mathrm{min} /$ $1.73 \mathrm{~m}^{2}$ the single nephron GFR has already reached its maximum. It is unlikely that any intervention can prevent or even halt the inexorable focal and segmental glomerulosclerosis that has been abundantly documented in rats and in a few human studies. The next step might be investigating the effect of a protein restricted diet in patients with a near normal glomerular filtration rate. However the disadvantages of keeping to such an unpleasant diet must be balanced against the risk for such a patient to progress to end stage renal disease.

The study was supported by the Dutch Kidney Foundation, Grant No C 87.648, and the Nutricia Research Foundation registration No S 155715. The study is also part of the 'European Study for Nutritional Treatment of Chronic Renal Failure in Childhood', BMFT grant No 07047420 (coordinator Professor O Mehls, BMFT grant

Parts of this study were presented to the 8th Congress of the International Pediatric Nephrology Association, September 1989, Toronto, Canada; to the 24th Congress of the European Society of Paediatric Nephrology, October 1990, Rome, Italy; to the 6th International Congress of Nutrition and Metabolism in Renal Disease, August 1991, Harrowgate, UK, and to the 9th Congress of the International Pediatric Nephrology Association, September 1992, Jerusalem, Israel.

We would like to thank W H L Hackeng for his enthusiasm and his contributions to the study.

1 Hostetter TH, Olson JL, Reunke HG, Venkatachalam MA, Brenner BM. Hyperfiltration in remnant nephrons: a potentially adverse response to renal ablation. Am $\mathcal{f}$ Physiol 1981; tially adverse

2 Brenner BM, Meyer TW, Hostetter TH. Dietary protein intake and the progressive nature of kidney disease: the role of hemodynamically mediated glomerular injury in the pathogenesis of progressive glomerular sclerosis in aging, renal ablation, and intrinsic renal disease. $N E n g l \mathcal{F} M e d$ 1982; 307: 652-9.

3 Kleinknecht C, Salusky I, Broyer M, Gubler M-C. Effect of various protein diets on growth, renal function, and survival of uremic rats. Kidney Int 1979; 15: 534-41.

4 Okuda S, Motomura K, Sanai T, et al. Effect of different levels of protein intake on renal deterioration and nutritional state in experimental renal disease. Clin Sci 1987; 73: 33-9.

5 Provoost AP, de Keijzer MH, Molenaar JC. Effect of protein intake on lifelong changes in renal function of rats unilaterally nephrectomized at young age. $\mathcal{F}$ Lab Clin Med 1990; 114: 19-26.

6 Salusky I, Kleinknecht C, Broyer M, Gubler M-C. Prolonged renal survival and stunting, with protein-deficient diets in renal survival and stunting, with protein-deficient diets in experimental uremia: reversal of these effects by addition amino acids. F Lab Clin Med 1981; 97: 21-30.

7 Jureidini KF, Hogg RJ, van Renen MJ, et al. Evaluation of long-term aggressive dietary management of chronic renal long-term aggressive dietary management of chro

8 Wingen AM, Fabian-Bach C, Mehls O. Low-protein diet in children with chronic renal failure - 1-year results. Pediatr Nephrol 1991; 5: 496-500.

9 Andre JL, Deschamps JP. Tension arterielle entre 4 et 18 ans. La Revue de Pediatrie 1978; 4 (suppl)

10 World Health Organisation. Energy and protein requirements. Report of a joint FAO/WHO/UNU expert consultation. Geneva: WHO Technical Report Series No 724, 1985; 95, 98, 105, 106.

11 Ministry of Health and Agriculture. What is eaten in the Netherlands. Results of the dietary assessment 1987-1988. Rijswijk: Ministry of Health and Agriculture, 1988.

12 CIVO Instituten TNO. Nederlands voedingsstoffen bestand 1986-1987. Stichting NEVO voorlichtings bureau voor de voeding. Zeist: CIVO-Instituten TNO, 1987. 
13 Kist-van Holthe tot Echten JE, Nauta J, Hop WCJ, et al. Protein intake cannot be estimated from urine urea excretion. Pediatr Nephrol 1992; 6: 85-7.

14 Schwartz GJ, Brion LP, Spitzer A. The use of plasma creatinine concentration for estimating glomerular filtration rate in infants, children and adolescents. Pediatr Clin rate in infants, children
North Am 1987; 34: 571-90.

15 Roede MJ, van Wieringen JC. Growth diagrams 1980 . Netherlands third nation-wide biometric survey. Tijdschrift voor lands third nation-wide biometric survey. Tijdsch
Sociale Gezondheidszorg 1985; 63 (suppl): 1-34.

16 Blumenkrantz MJ, Kopple JD, Gutman RA, Chan YK, Barbour GL. Methods for assessing nutritional status of patients with renal failure. Am f Clin Nutr 1980; 33: 156785.

17 Rosman JB, Langer K, Brandl M, et al. Protein-restricted diets in chronic renal failure: a four year follow-up shows limited indications. Kidney Int 1989; 36 (suppl 27): S96-102.

18 Locatelli F, Alberti D, Graziani G, Buccianti G, Redaelli B, Giangrande $A$, and the Northern Italian Cooperative Study Group. Prospective, randomised, multicentre trial of effect of protein restriction on progression of chronic renal insufficiency. Lancet 1991; 337: 1299-304.

19 Ihle BU, Becker GJ, Whitworth JA, Charlwood RA, KincaidSmith PS. The effect of protein restriction on the progression of renal insufficiency. N Engl F Med 1989; 321:1773-7.

20 Kleinknecht $C$, Broyer M, Huot D, Marti-Henneberg C Dartois AM. Growth and development of nondialyzed Dartois AM. Growth and development of nondialyzed
children with chronic renal failure. Kidney Int 1983; 24: children

21 Rees L, Rigden SPA, Ward GM. Chronic renal failure and growth. Arch Dis Child 1989; 64: 573-7.

22 Chantler C, Holliday MA. Growth of children with renal disease with particular reference to the effects of calorie malnutrition: a review. Clin Nephrol 1973; 1: 230-42.

23 Hellerstein S, Holliday MA, Grupe WE, et al. Nutritional management of children with chronic renal failure. Pediatr Nephrol 1987; 1: 195-211.

24 Mehls O, Wingen AM, Bonzel KE, Ruder $\mathbf{H}$, Tonschoff $B$ Protein restriction in children with chronic renal failure? Blood Purif 1989; 7: 46-51.

\section{Alcohol and the European fetus}

A supplement to the International Fournal of Epidemiology (EUROMAC 1992; 21: suppl 1) is devoted to a review of the literature about maternal alcohol consumption and the fetus and a report of a multicentre study initiated by the European Commission and carried out in the Netherlands, Denmark, Germany, France, Portugal, Spain, and Scotland. Mothers were questioned about their alcohol consumption during pregnancy and their babies were examined at birth and their development assessed at 18 months. The frequency with which mothers admitted to high alcohol intakes $\left(\geqslant 120 \mathrm{~g}\right.$ alcohol per week $\left.{ }^{\star}\right)$ varied greatly from $0.5 \%$ in one Spanish centre to $19.4 \%$ in the French centre.

The main finding was that fetal growth was adversely affected when mothers drank $120 \mathrm{~g}$ or more of alcohol weekly. No adverse effects were found for modest alcohol intakes. A diagnosis of fetal alcohol syndrome was not made for any baby in the study, which included 8484 pregnancies. They found no adverse effect on development at 18 months for any level of alcohol intake during pregnancy, in fact, embarrassingly enough, there was a tendency for the babies of drinking mothers to perform better and a statistically significant trend for the toddlers' attention span to increase with maternal alcohol intake.

The authors conclude that one standard drink a day is unlikely to harm the fetus, although they recommend on a 'benefit of the doubt' basis that pregnant mothers should not drink alcohol. They also warn against 'binge' drinking.

ARCHIVIST

$\star$ The alcohol content of one glass of these drinks is as follows: beer $(280 \mathrm{ml})=8 \cdot 5 \mathrm{~g}$, Pils $(280$ $\mathrm{ml})=17.9 \mathrm{~g}$, wine $(125 \mathrm{ml})=11.0 \mathrm{~g}$, sherry $(50 \mathrm{ml})=7.2 \mathrm{~g}$, and spirits $(30 \mathrm{ml})=9.6 \mathrm{~g}$. 